\title{
Species-area model predicting diversity loss in an artificially flooded cave in Brazil
}

\author{
Rodrigo L. Ferreira ${ }^{1,2^{*}}$ and Thais G. Pellegrini ${ }^{2}$
}

${ }^{1}$ Centro de Estudos em Biologia Subterrânea, Setor de Zoologia Geral, Departamento de Biologia, Universidade Federal de Lavras, Minas Gerais, Brasil ${ }^{2}$ Programa de Pós-Graduação em Ecologia Aplicada, Departamento de Biologia, Universidade Federal de Lavras, Cx Postal 3037, Campus Universitário, CEP 37200-000, Lavras, Minas Gerais, Brasil

\begin{abstract}
Subterranean environments are poorly known regarding many ecological aspects, such as community structure and its response to different disturbances. To estimate the effects of ground area lost in a limestone cave community in Southeastern Brazil, the invertebrate fauna was sampled before $76 \%$ of the cave floor was submerged by the filling of a hydroeletric power plant reservoir. Then, a 2-year monitoring was conducted. A species-area curve based on empiric data was constructed and the $z$-value of the species-area equation was calculated, what allowed estimating the expected cave richness after flooding comparing with data obtained during the monitoring. The results support the species-area relationship hypothesis; the cave community showed a drastic reduction of richness after losing area. Furthermore, it was also possible to estimate the species richness using the species-area equation. Moreover, the cave community showed a high temporal beta diversity when comparing the community sampled before and after the inundation; this pattern becomed less pronunciated over time. A high $z$-value $(z=0.58)$ was found for the cave species-area equation, indicating that subterranean communities are even more damaged by area loss than other environments probably due to the reduced mobility of cave invertebrates and the physical isolation of this environment. The present study highlighted that area loss resulted in a drastic reduction of cave richness. Additionally, it became evident that whenever possible studies should consider the original condition of a cave community and their responses after disturbances. Such strategy is critically important for conservation purposes.
\end{abstract}

Keywords: $\quad$ invertebrates, community, human disturbance, conservation, beta diversity, z-value Received 20 December 2018; Revised 11 June 2019; Accepted 14 June 2019

Citation: Lopes F.R. and Pellegrini T.G., 2019. Species-area model predicting diversity loss in an artificially flooded cave in Brazil. International Journal of Speleology, 48 (2), 155-165. Tampa, FL (USA) ISSN 0392-6672 https://doi.org/10.5038/1827-806X.48.2.2244

\section{INTRODUCTION}

The species-area relationship is well recognized by the scientific community (May et al., 1995), representing one of the most robust patterns in ecology (Cencini et al., 2012). Larger areas typically support more species when compared with smaller ones (MacArthur \& Wilson, 1963). This relationship is explained by the area effect on immigration and extinction rates, stated by the Equilibrium Theory of Island Biogeography (MacArthur \& Wilson, 1963; Wilson, 2010), and also by the presence of additional ecological niches (Williams, 1943; Connor \& McCoy, 1979).

Cave ecosystems are pointed by some authors as "islands-like" environments (Culver, 1970; Iliffe et al., 1983; Culver \& Pipan, 2009). The subterranean space delimited by the rock is the "island" and the "ocean" can be considered the non karstic area surrounding the karst, or the surface environment connecting different "islands" (Culver, 1970; Culver \& Pipan, 2009). This surface environment is an inhospitable habitat and isolates specially the terrestrial invertebrates in caves by the sunlight, geological boundaries and ecological restrictions (Culver et al., 1973; Culver \& Pipan, 2009). In subterranean systems, the environmental variation, especially temperature and moisture, are lower than the observed in the surrounding external environments (Poulson \& White, 1969). The more isolated a karst area is, the lower immigration and extinction rates are, which are differentiated for terrestrial and aquatic invertebrates (Culver et al., 1973). Furthermore, considering the environmental stability of caves, their inhabitants may present quick responses to environmental changes, especially invertebrates, the most abundant cave dwellers (Hodkinson \& Jackson, 2005). Invertebrates may sign environmental disturbances through their 
responses, from individual specimens to populations or even community level, acting as good bioindicators (Hodkinson \& Jackson, 2005).

Nowadays, karst areas have been under intense exploration by human due to mining activities, energy demand, agricultural practices and growth of unbridled tourism (Eberhard, 2001; Romero, 2009; Jaffé et al. 2018; Rabelo et al., 2018). Unfortunately, human alterations on the cave environments and surrounding habitats are leading to serious damages to subterranean ecosystems, resulting in changes in the physical properties of the cave athmosphere and water; increase of sediment influx into caves; soil compaction by visitors stepping; development of "lampenflora"; entrances and walls enlargement (and/ or obstruction); reduction of the cave area by erosion or inundations; nutrient input alteration or disrupt; or even an entire cave suppression (Romero, 2009; Shneider et al., 2011; Pellegrini \& Ferreira, 2012; Mulec, 2014; Rabelo et al., 2018). As a consequence of human impacts, the terrestrial cave fauna can responds in different ways by losing species; decreasing the phylogenetic diversity; being invaded by exotic species; or even changing the composition, structure and temporal/spatial dynamics of invertebrate communities (Ferreira \& Horta, 2001; Shneider et al., 2011; Pellegrini \& Ferreira, 2012; Jaffé et al., 2018).

Most studies evaluating human disturbances on biodiversity occur after the disturbance has taken place. In order to measure the impact on a community, many researches are conducted using spatially distinct sites to determine the unimpacted reference condition (França et al., 2016). In subterranean environments, it is not unusual to compare the reference condition in the same cave using disturbed and undisturbed chambers and conduits, specially for impacts due to tourism activities (e.g. Bernardi et al., 2010; Barciová et al., 2010; Pellegrini \& Ferreira, 2012, Faille et al., 2014). However this approach may underestimate the consequences on local species diversity and community turnover (França et al., 2016). Very few studies consider before-after differences due to human alteration in cave environments (e.g. Moldovan, 2003; Faille et al., 2015), though this kind of studies are extremely important for conservation purposes in caves.

Considering that the cave size is directly related to the cave invertebrate richness (Culver et al., 1973; Culver et al., 2004; Ferreira, 2004; Souza-Silva et al., 2011; Batucan et al., 2013; Simões et al., 2015, Jaffé et al., 2016), the species-area equation could be used to estimate how many species will be extinct as a result of area loss (Simberloff, 1992). Given the fact that we had the prior information that Santo Antônio Cave, located in southeastern Brazil, would be partially submerged by the construction of the reservoir, this study aimed to evaluate the effects of ground area loss by a flooding process in a cave under the terrestrial invertebrate community. Our initial hypothesis was that the effects of the area reduction would be more severe for cave communities than for those for epigean environments especially due to the species isolation and low dispersal capability. It is important to highlight that many Brazilian caves do not present as many troglobitic species as caves from temperate regions, which can lead to different patterns of area effect on species loss/gain rates. Based on this hypothesis we proposed a management action that would tentatively reduce the impact of the reservoir filling over the community. For this purpose, we evaluated the i) species loss; ii) species turnover; iii) temporal beta diversity partitioning; $i v$ ) we determined and evaluated the $z$ value (a fitted constant from the species-area equation), and finally, we described how richness changed with area loss (Tjørve \& Tjørve, 2008).

\section{MATERIAL AND METHODS}

\section{Study Area}

The study was conducted in Santo Antônio Cave $\left(21^{\circ} 11^{\prime} 50.04^{\prime \prime S}, \quad 44^{\circ} 51^{\prime} 02.89^{\prime \prime} \mathrm{W}\right)$, a very isolated cave (the closest cave is located around $70 \mathrm{~km}$ far from it) inserted in the smallest carbonate group in Minas Gerais state (Brazil), called the São João Del Rey carbonatic group. Accordingly, no caves are known in it surroundings, which contributes to the cave isolation. The cave is located in the Itumirim municipality, which comprises a transitional area between the Cerrado (Brazilian Savannah) and the Atlantic Rainforest Biome. Santo Antônio Cave is a limestone cave with 250 meters long and presents four entrances, which are large, leading to a high interference from the surface on the cave environment. Therefore, the sunlight indirectly reaches most of the cave conduits (which are disphotic), although there is at least one aphotic and stable chamber in the cave, that was initially inhabited by a colony of vampire bats - Desmodus rotundus (Geoffroy, 1810) - with hundreds of individuals producing a guano pile.

The region has already suffered human alteration by limestone extraction during the middle $20^{\text {th }}$ century. Such activity partially altered the cave, especially by expanding the existing fractures, leading to the collapses of rocks (which, in turn, enhanced the size f one entrance), conduits silting and speleothems destruction. Moreover, the mining company constructed a dam that diverted a small drainage that used to run inside the cave. Despite the lack of scenic attractions of Santo Antônio Cave (the cave do not present many speleothems), after the end of the mining activity, the touristic/religious use of the cave started. In 2002, the cave was partially (and permanently) flooded by the development of the Funil Hydropower Plant Reservoir. Before the flooding, a footbridge was constructed, leading to a small altar located close to the main entrance (Fig. 1).

\section{Sampling methods and management plan}

Before the inundation event, on October 2002, the invertebrate fauna was sampled along the whole cave, during ten hours by four experient speleobiologists. The invertebrate collection was conducted by the visual searching method, using tweezers and brushers, paying special attention to microhabitats such as under rocks and deposits of organic matter. 


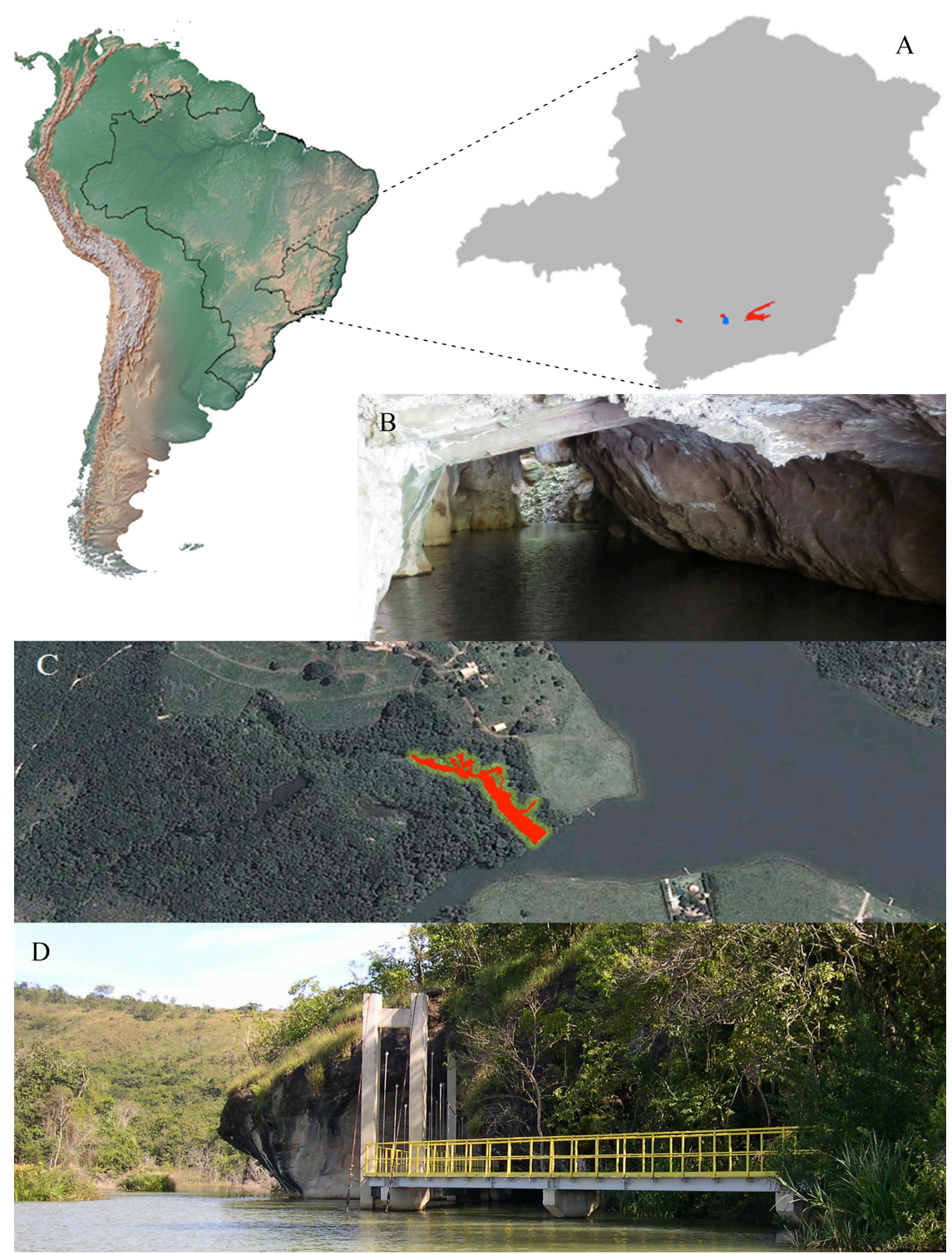

Fig. 1. A) Cave localization in Brazil, in detail the localization at Minas Gerais state. Red areas are indicating the carbonatic province of the São João Del Rei Group. The blue area represent Itumirim municipality; B) A cave conduict after flooding; C) Cave location in relation to the reservoir; D) Footbridge constructed after the reservoir filling for touristic purposes. of the cave in three areas (especially vegetal debris collected from the area that would be submerged in the cave). These upper habitats received the invertebrates.

However this methodology was not fully effective, especially considering the smaller invertebrates that could easily hide in small cracks in the soil, escaping from the catch. Hence, during the filling of the reservoir and consequent innundation of the cave floor, many invertebrates would be "trapped" in the small "islands" that would be formed in the cave floor, given its topographic roughness. Considering this scenario, the future "islands" were previously determined through the elaboration of a detailed topographic map of the cave floor, which indicated elevated areas that would became small islands, trapping invertebrates during the inundation (Fig. 2). In order to connect the "islands" formed during the inundation to the upper areas that would not be submerged, small wood bridges were installed, preferably directed to the areas where the new structured microhabitats were created (Fig. 2).

The visual searching method was also used in the monitoring of the cave community after the inundation. This methodology was apllied in a four hour sampling effort in each visit to the cave (also performed by four speleobiologists). Such monitoring occurred during two years, with samplings occuring at intervals of three months, with a total of eight collecting events.
Each species was represented by a number plotted on a cave map in the location where it was captured or observed, following the methodology proposed by Ferreira (2004). In laboratory, the species were identified to the lowest taxonomic level possible, thus determining the cave species richness. This first sampling event enabled the detection of areas with the higher species concentration (richness).

Based on this inventory, it was possible to propose a management plan for Santo Antônio Cave, which aimed to reduce the species loss by drowning. Thereby, three days before the inundation (in December 2002), invertebrates were manually captured and placed into higher areas that would not be submerged. Those areas were previously prepared to receive the invertebrates, by enriching the substrate structure adding rocky shelters (coming from the flooded areas) and pieces of wood. Since those upper regions of the cave used to be drier than the substrates from the bottom part (being devoid of invertebrates), the area was also humidified, adding water to moisten the dry soil substrates. Finally, other organic debries were added for trophic enrichment in the upper zones

\section{Data analyses}

The first inventory (prior to the inundation) and two years monitoring data were analyzed by means of the BoundarySeer program version 1.2.0 (TerraSeer Inc. Software for Geographic Boundary Analysis, http://www.terraseer.com) to evaluate migration and extinctions events on the cave after the inundation. This analysis provides a spatial representation of the richness gradient on the cave map by a color scale, the yellowish colors represent values of low richness while reddish colors represent high values. For this purpose, the cave map was divided in squares of $2 \mathrm{~m}^{2}$ and the richness was estimated for each square (for each monitoring event). This method of spatial representation of species richness distributions by color scales was already applied in cave entrance environments (Prous et al., 2015).

The similarity in the fauna of all sampling years, including before the inundation, was compared using non-metric multidimensional scaling ( $n-M D S$ ) ordination through the Jaccard method, that is an incidence-based index (Chao et al., 2006), using the 

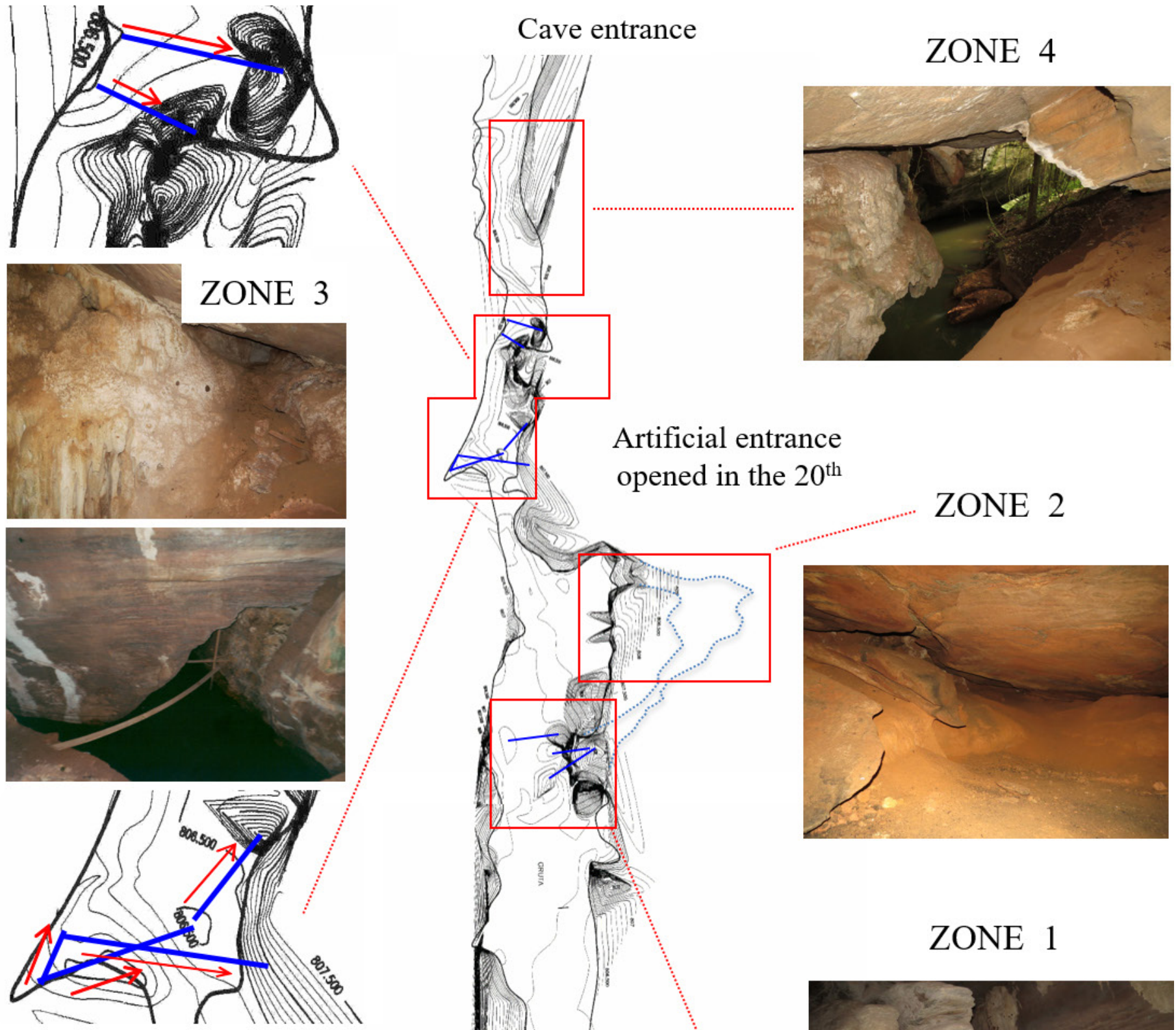

Migration bridges

$\overrightarrow{\text { Migration movements }}$ direction

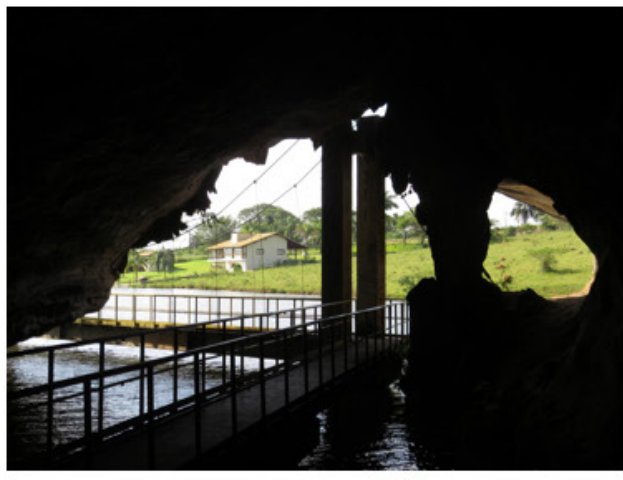

\section{Main cave entrance}

Artificial entrance opened in the $20^{\text {th }}$

\section{ZONE 2}

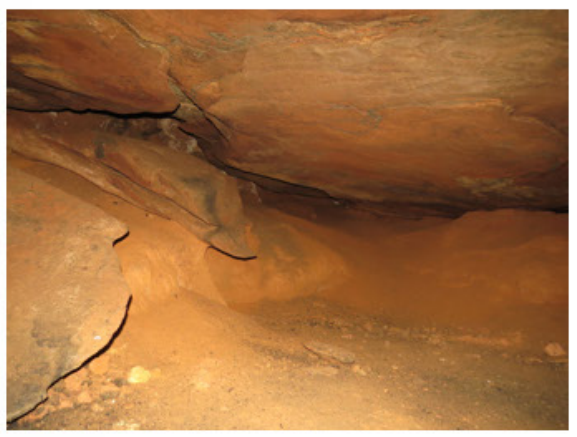

\section{ZONE 1}

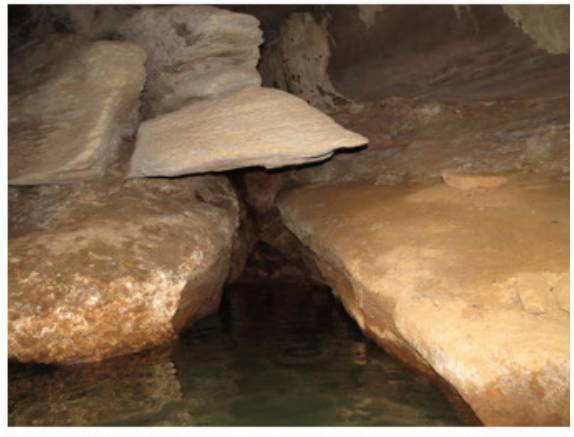

Fig. 2. Detailed topographic map of the main conduct of the cave floor indicating the small wood bridges installed for invertebrate migration for safe areas. 
function metaMDS from the VEGAN package. The existence of significant differences between $n-M D S$ groups was evaluated by analysis of similarities (Clarke \& Gorley, 2001), using the function ANOSIM also from the VEGAN package. Furthermore, the species richness and an additional $n-M D S$ ordination through the Jaccard index were used to describe spatial and temporal differences in the community composition between each of the four zones before and after the flooding. For each n-MDS from the different sampling years and also from the zones, it was evaluated the homogeneity of group dispersions (in relation to the centroid of their dispersions) using the betadisper function, Jaccard method, from vegan package. Graphical information was obtained from both $n-M D S$ and constructed through the function GGPLOT from the GGPLOT2 package. All previously mentioned analyses and graphics were conduced in $\mathrm{R}$ program version 3.5.0 (R Core Team, 2016).

Changes in species composition from pairwise comparisons in sampling-to-sampling events were estimated by calculating temporal differences between assemblages - temporal beta diversity. The beta diversity can be a result of species substitution (turnover) or species loss or gain (nestedness), and it is possible to disentangle the contribution from each component by partitioning beta diversity (Baselga \& Orme, 2012). Beta diversity partitioning was calculated using the BETA.TEMP function of the BETAPART package (Baselga et al., 2017). Such function comput Sørensen and Jaccard dissimilarities indices, both monotomic transformations of beta diversity, into two separate components. The indices determine turnover and nestedness, respectively (Baselga \& Orme, 2012). Finally, a bar graphic was constructed using the GGPLOT function of the GGPLOT2 package (Wickham, 2009). All previously mentioned analyses were conduced using $\mathrm{R}$ software version 3.5.0 (R Core Team, 2016).

A species-area curve was constructed to infer about the loss of cave invertebrates with the area loss. For this purpose, we used data from 28 limestone caves from Minas Gerais state (Brazil), including the Santo Antônio Cave prior to the flooding. The most commonly fitted model for species-area curve is the equation $S=$ $c A^{z}$ (where $S$ is number of species, $A$ is area, and $c$ and $z$ are fitted constants). This equation can be linearized by $\log$-tranformation: $\log S=\log c+z \log A$, while the $z$ is the rate at which slope decreases with area and $c$ is often denoted as the $S_{0}$ (Tjørve $\&$ Tjørve, 2008). Based on this assumption, the richness and area of the 28 caves were log-transformed and the $z$-value obtained. In order to verify if our model would be appropirate for the predicted data, a GLM (generalized linear model) analyses were performed using the function GLM.NB in the MASS package. Since data was nonparametric, the error distribution with the best fit was negative binomial (Normality was tested by the Shapiro-Wilk test). Then we represented the result graphically using the function GGPLOT from the GGPLOT2 package in $\mathrm{R}$ program version 3.5.0 ( $\mathrm{R}$ Core Team, 2016). Then it was possible to predict the species expected to be found in Santo Antônio Cave after flooding using the species-area equation $S_{1}=S_{0}\left(A_{1} / A_{0}\right)^{z}$; in which: $\mathrm{S}_{1}=$ final richness, $\mathrm{S}_{0}=$ initial richness, $\mathrm{A}_{1}=$ final area, $\mathrm{A}_{0}=$ initial area, and $z=$ constant (Rybicki \& Hanski, 2013).

\section{RESULTS}

In the first collection, before the inundation, 92 species were observed, distributed into 45 families belonging to the orders "Acari", Aranae, Opiliones, Palpigradi, Pseudoscorpiones, Scorpiones, Isopoda, Spirostreptida, Symphyla, Lithobiomorpha, Blattodea, Coleoptera, Collembola, Diptera, Orthoptera, Hemiptera, Hymenoptera, Lepidoptera, Psocodea and Tricladida (Appendix 1). None of the species found are troglobitic, and the community is mainly composed by troglophiles (Fig. 3).

After the first inventory, it was possible to define four main zones regarding higher species richness concentration prior to the reservoir filling in the cave (Fig. 2). The first zone is located in the cave main conduit. The zone 2 is the aphotic chamber with the colony of vampire bats - Desmodus rotundus. The guano deposit produced by the bats attracted many invertebrates to the cave and represented the most populated area. The third zone corresponded to a region in which there were some deposits of vegetable debris, which attracted many invertebrates. Finally, the fourth zone was situated near one of the entrances, which corresponded to a shelter for many para-epigean species. The second zone was the only area that was not submerged. The other three zones (all associated to the main cave floor) became

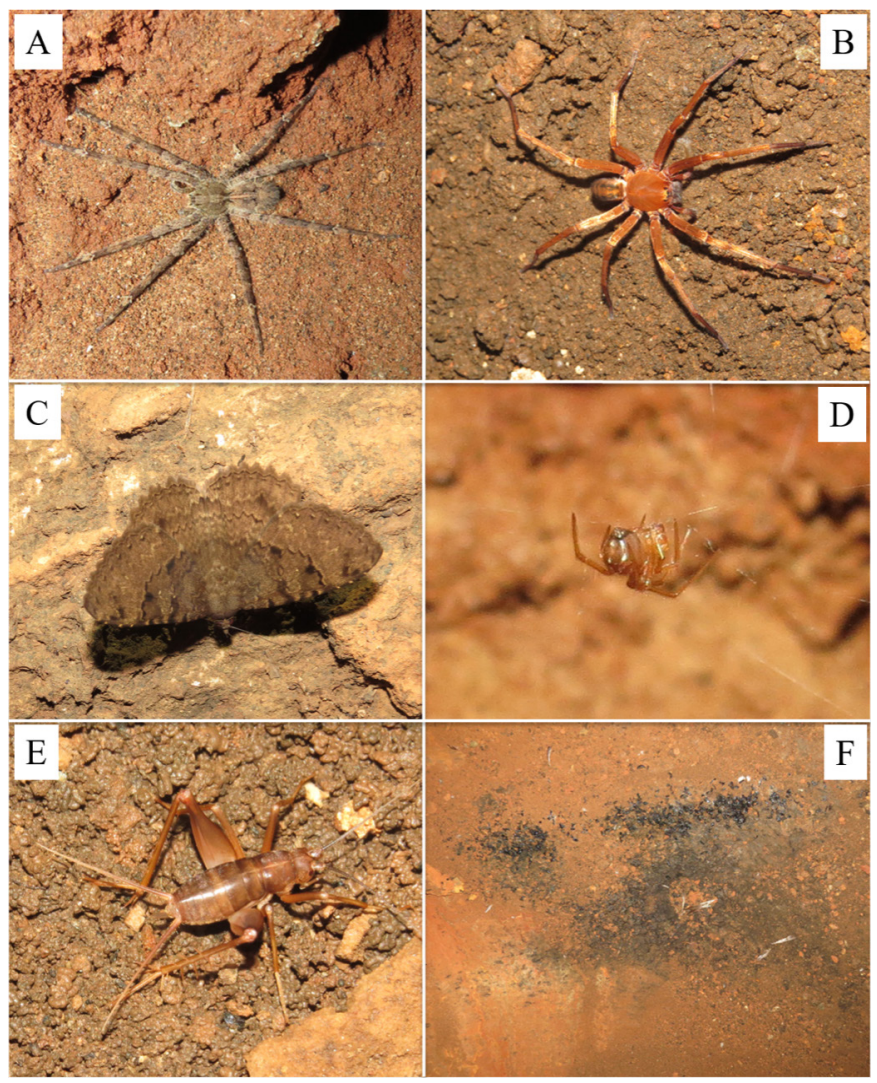

Fig. 3. Photographs of some species and food resources of the study. A) Enoploctenus sp.; B) Isoctenus sp.; C) Latebraria sp.; D) Theridion sp.; E) Endecous sp.; F) Guano of Desmodus rotundus pile found in zone 2. 
totally unavailable for terrestrial invertebrates in their original areas. The nearby upper areas (for which the invertebrates were relocated) use to be devoid of invertebrates before the flooding. Except for the second zone, organisms from the other three areas were relocated after the flooding.

As the reservoir was filled, $76 \%$ of the cave floor was submerged. After that, it was possible to observe the migratory movements and local extinctions in the community (Fig. 4). The community suffered a notable species loss right after the inundation, as observed in the first monitoring inventory (Fig. 5). A total of 61 species were no longer observed after the area loss caused by the inundation. The bat population (Desmodus rotundus), that initially presented around 200 individuals, migrated to another shelter during the reservoir filling. In the third monitoring it was possible to see that about ten bats returned to the cave. Some invertebrate species, not found during the second monitoring, were visualized in the third monitoring, increasing the species richness (Fig. 5). From that monitoring on, a subtle variation on species richness was observed. It is importat to point out that the community rapidly colonized the nonsubmerged areas of the cave, some of which that used to be extremely dry before the inundation (and devoid of organisms). From the second monitoring on (May

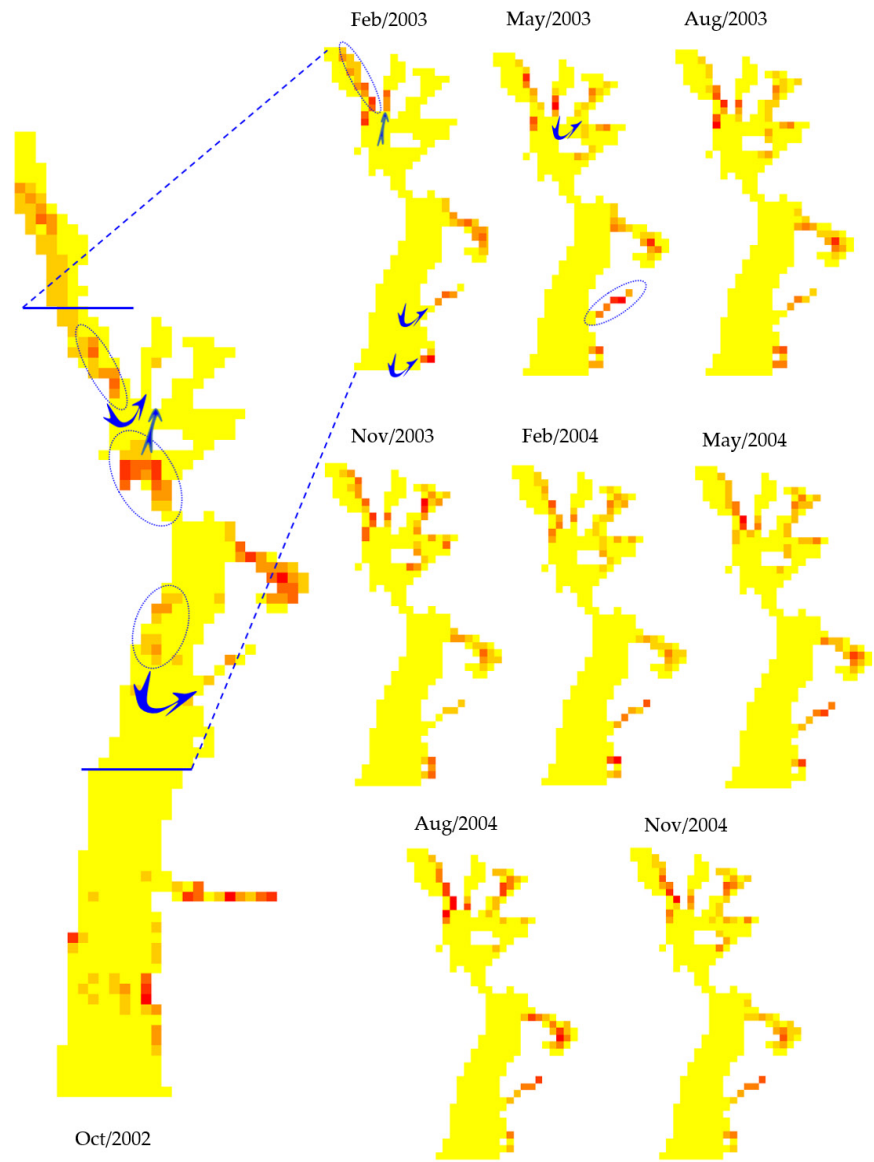

Fig. 4. Maps of species richness gradient represented by a color scale in Santo Antônio Cave, Minas Gerais, Brazil, along two years. The greater and the minor maps show the species richness before the reservoir filling and the variations in the species richness distribution over time, respectively. The gradient color, from yellow to red, indicates the increasing of species-rich values. Blue arrows indicate the dispersal and colonization direction. Blue circles indicate source areas of species dispersal. The small green rays represent local extinction.

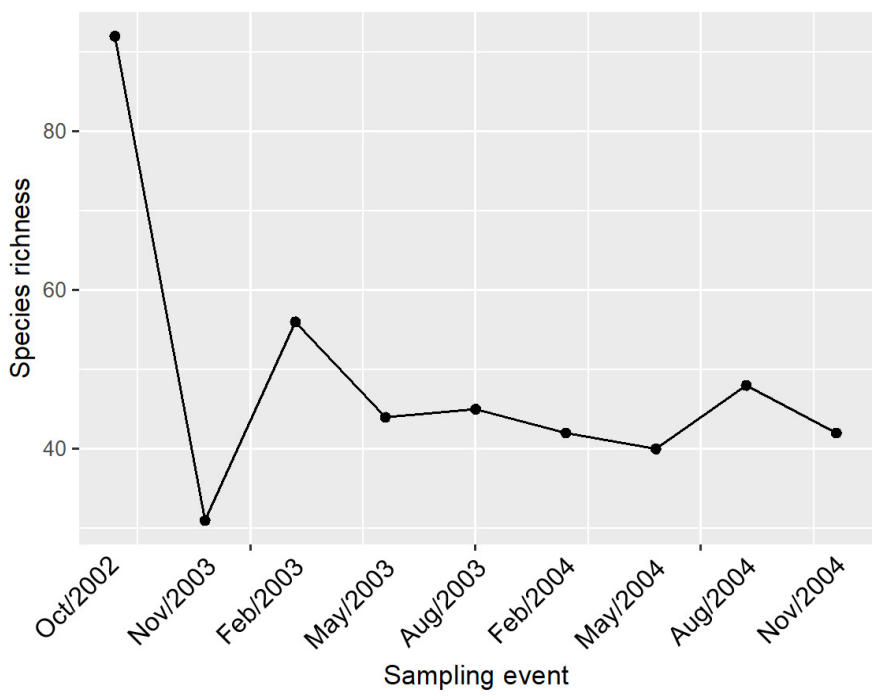

Fig. 5. Oscillation of species richness over time at Santo Antônio Cave, Minas Gerais, Brazil. The richness sharp decline is coincident with the reservoir filling.

2003), most of the emerging areas within the cave were already colonized (Fig. 4).

The community showed a high dissimilarity between the species sampled before and after the cave inundation (Fig. 6a). However, the dissimilarities became less evident when comparing the first and the second year of monitoring. Furthermore, the dissimilarity among the first sampling, samplings along the first year and along the second year of monitoring were significantly different $\left(R_{\text {ANOSIM }}=0.34\right.$; $p=0.042$; Fig. 6a). Finally, the similarity between the communities sampled in each monitoring event has increased during the first year after the inundation of the cave, but decreased along the second year. All monitored zones presented, in average, a species richness reduction after flooding (Table 1) and high community structural differences within each cave zones were also evident (Fig. 6b). It was possible to observe that zone 1 was the most affected, presenting high dissimilarities along time when compared to the first sampling event (before the flooding - average dissimilarity of 0.95). Zone 3 and zone 4, the most connected to the external environment, showed dissimilarities values of 0.93 and 0.88 , respectively. Zone 2, which correspond to the more stable chamber presenting bat guano (that was not flooded) was the less impacted, with an average dissimilarity value of 0.84. Regarding the variation of the community in each zone after the flooding, zone 1 was the most variable, with an average distance to the centroid of the dispersion points corresponding to 0.61 (Fig. $6 b)$. Zone 2 was the less variable, with a distance corresponding to 0.57 (Fig. 6b). Finally zones 3 and 4 presented very similar average distances to the centroid of their dispersion points, corresponding to 0.58 and 0.59, respectively (Fig. 6b).

Considering the Santo Antônio Cave as a whole, the total beta temporal diversity reached higher values in the first two pairwise comparisons (the first sampling event prior to the filling and the first two monitorings), ranging from 0.67 to 0.72 (Fig. 7). The nestedness component was expressively higher considering the first two pairwise comparisons $(0.32-0.11)$ due to 

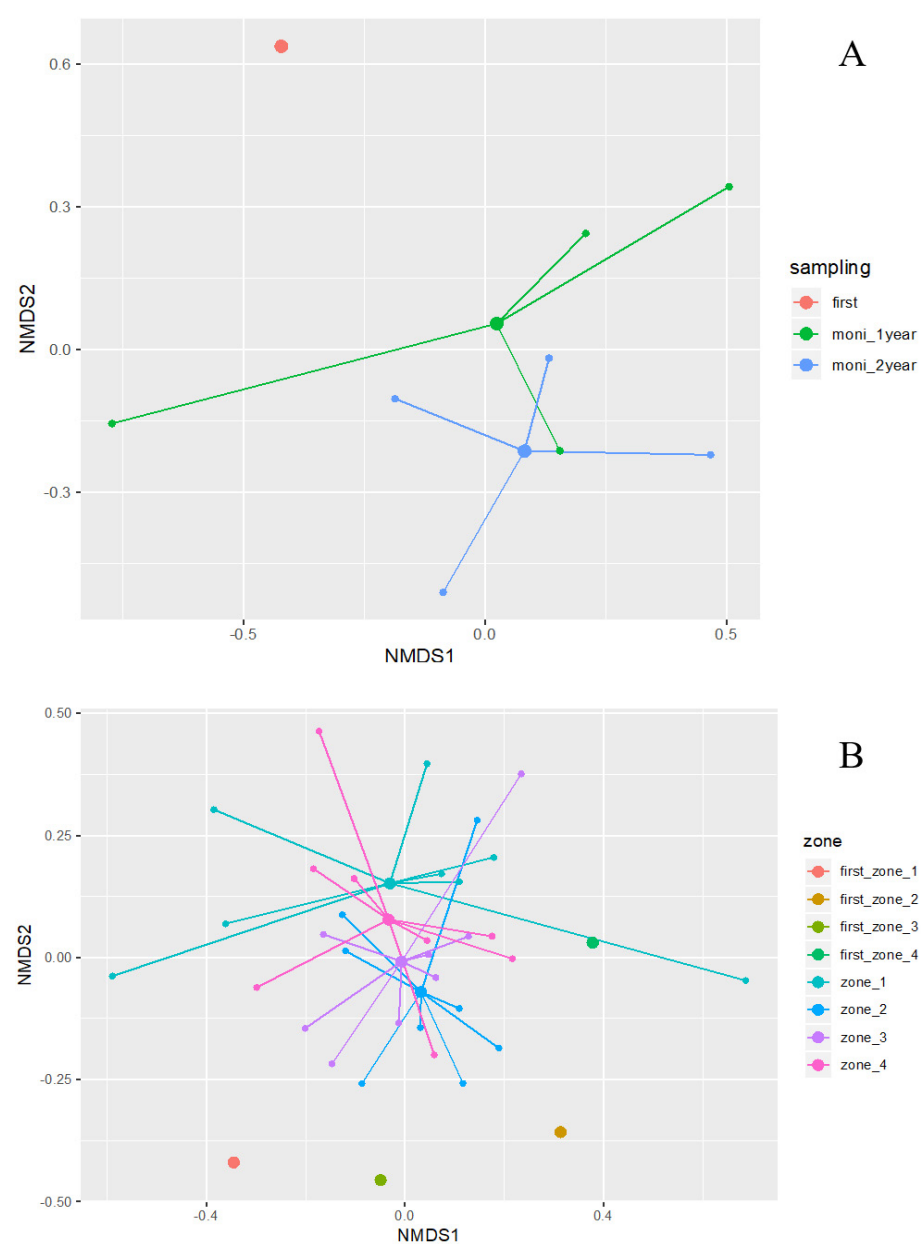

Fig. 6. Non-metric multidimensional scaling showing the similarities of invertebrate fauna of Santo Antônio Cave with the representation of the centroid for each group of data dispersions (variation). A) The points represent the whole community of Santo Antônio Cave in each sampling event. The groups with different colours are representing, in red, the first sampling (before flooding) and the two years of minitoring after the reservoir filling, in green is the first year and in blue the second year; B) The points represents the community found in each zone along time. The groups with different colours are representing each of the four sampling zones.

intense species loss, becoming smaller over time. After the third monitoring event, it ranged from 0.06 to 0.01 . The species turnover was not expressively high in the first pairwise comparisons, but it reached higher values and stabilized over time.

The species loss in function of area loss in Santo Antônio Cave was predicted by the species-area curve, witch explained $47.6 \%$ of the data variation $\left(\mathrm{R}_{\text {GLM.NB }}^{2}=0.476, \mathrm{p}<0.001\right.$, Fig. 8), from which it was possible to obtain the constant $z=0.58$. Considering the species-area relationship equation, the species richness in Santo Antônio Cave after the inundation was estimated at 40 species. The mean richness found in the cave along the monitoring after the inundation corresponded to 44 species.

\section{DISCUSSION}

The effect of habitat reduction on species richness is one of the most frequently studied patterns in biodiversity (Lomolino, 2001). A fairly common approach in this perspective is the species-area relationship (May et al., 1995). Caves and karst areas have been already described as islands for decades (Culver et al., 1973). However, this theme was poorly
Table 1. Species richness within each of the four zones before and after flooding found in all monitoring events.

\begin{tabular}{|l|c|c|c|c|}
\hline Sampling event & Zone 1 & Zone 2 & Zone 3 & Zone 4 \\
\hline Dec/ 2002 & 10 & 17 & 27 & 37 \\
\hline Feb/ 2003 & 9 & 7 & 3 & 17 \\
\hline May/ 2003 & 7 & 16 & 30 & 18 \\
\hline Aug/ 2003 & 9 & 17 & 22 & 14 \\
\hline Nov/ 2003 & 7 & 14 & 20 & 9 \\
\hline Feb/ 2004 & 12 & 22 & 18 & 12 \\
\hline May/ 2004 & 3 & 21 & 10 & 11 \\
\hline Aug/ 2004 & 3 & 6 & 27 & 20 \\
\hline Nov/ 2004 & 6 & 17 & 15 & 8 \\
\hline
\end{tabular}

explored in caves, specially considering invertebrate communities (e.g. Snowman et al., 2010; Faille et al., 2015). The species-area relationship has been shown for bat assemblages in tropical Mexican caves, where the ceiling area strongly affects the number of bat species roosting in a cave (Brunet \& Medellín, 2001). The cave area is also a key predictor of the invertebrate species richness, the presence of troglobites and the presence of bat populations in Brazilian iron ore caves (Jaffé et al., 2016). Christman and Culver (2001) used the "Habitat Diversity Model" to search for subterranean invertebrate distribution patterns. This model assumes that there is a correlation between available niches, species richness and the sampled area (Williams, 1943; Connor \& McCoy, 1979). Following this model, Christman and Culver (2001), studying caves in US, concluded that habitat availability (the number of islands) and not their size, influences the richness of troglobitic species.

The species-area relationship quantifies the area effect on species richness (May et al., 1995; Pimm, 1995). Furthermore, the derived species-area relationship equation can be used to estimate how many species become extinct as a result of habitat reduction (Simberloff, 1992; Thomas et al., 2004). Our results support the species-area relationship hypothesis: the community of Santo Antônio Cave showed a drastic richness reduction after the area loss. Moreover, the richness and temporal beta diversity seems to reach a certain stability with time. On the other hand, although the dissimilarities

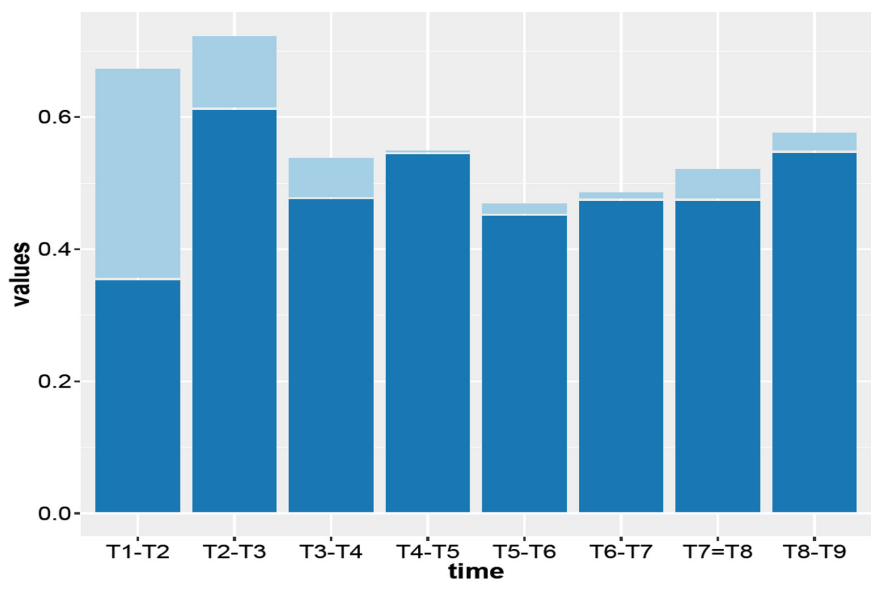

Fig. 7. Temporal beta diversity components from pairwise comparisons in sampling-to-sampling events. The componentes values are represented in dark blue for species substitution (turnover) and in light blue for species loss or gain (nestedness). 


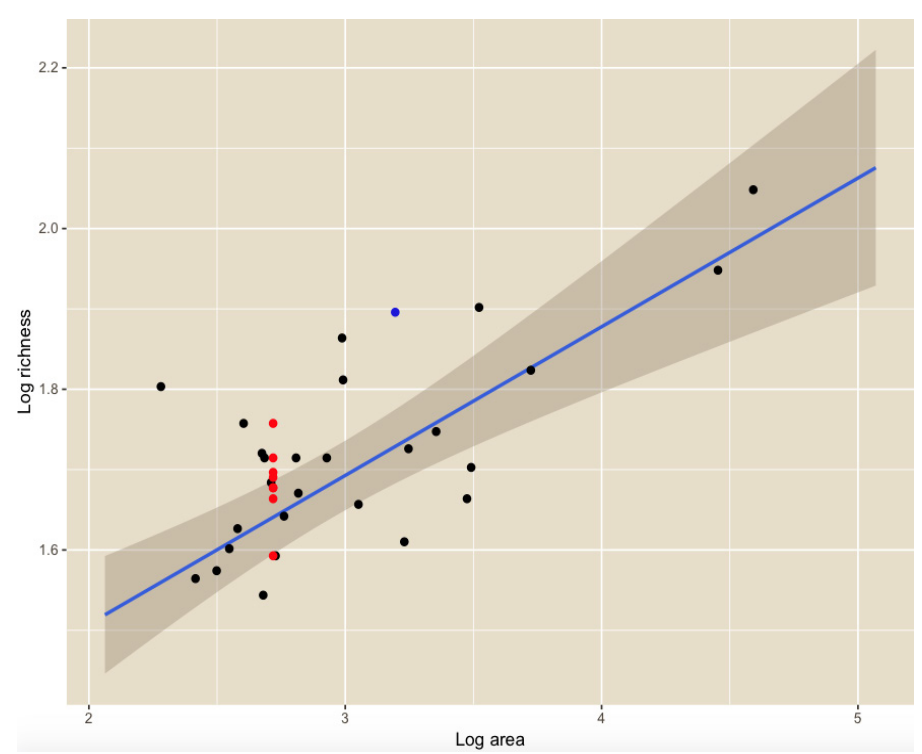

Fig. 8. Species-area curve. The blue dot represent the Santo Antônio Cave before the flooding, while the red dots represent the distinct monitoring samplings.

presented by the community became less evident with time, the similarity did not exceed 0.37 between two subsequent sampling events, and species turnover remained around 0.5. Accordingly, the species composition did not stabilized. However, given the number of entrances present in this cave, the contribution of acidentals or even "transient" species is certainly considerable. Hence, new "eventual" species will always be introduced in the system, and the similarity between sampling events probably will not achieve high values over time.

It is important to highlith that all the zones within the cave were severly impacted when comparing their original composition with the composition after the flooding. However, subtle differences were observed between the zones. Considering each zone, one would expect that the totally flooded areas would be the most impacted. This was especially true for the zone 1 , which presented the higher dissmilarites both when comparing the initial composition of the fauna (before the flooding) and the composition variation along the monitoring. Such variations might be related to the original area of the main cave floor (that was flooded) compared to the available remaining upper area after the flooding, that was considerably reduced in this zone. Hence, this reduced space might have induced competitive interactions that might have caused the considerable variations on invertebrate composition observed along the monitoring, though this is speculative. However, the zones 3 and 4 (that were also totally submeged) presented lower dissimilarity values when comparing the initial composition of the fauna and the composition variation along the monitoring. This could be explained by two main factors: i) both zones are located close to entrances, thus presenting especially para-epigean fauna (in which there is a great contribution of external species). Hence, potential external colonizers could rapidly return to shelter themselves after the flooding, in the upper areas of those zones; ii) alternatively, the manajement (wood bridges) could have acted more efficiently in those zones. Finally, the zone 2, that was the only not submerged, presented, in average, the lowest variations within the cave (being also the only trully aphotic area on the cave). Even with the severe reduction on the bat population just after the flooding (which led to a considerably reduction on guano deposition), the community was the less variable along time, corroborating a tendency towards the relation between environment stability and community stability in caves (Di Russo et al., 1997; Bento et al., 2016). Alternatively, species associated directly or indirectly to guano piles tend to belong to some specific groups in Brazilian caves (Ferreira \& Martins, 1999), what could have contributed to this pattern.

Nevertheless, the habitat loss reduces the available spaces to be colonized by new species, therefore reducing the balance between the colonization rate and the rate at which resident species are extinct (MacArthur \& Wilson, 1967). The knowledge regarding this balance can predict future losses, and this relationship was already confirmed for 25 hotspots of biodiversity around the world (Brooks et al., 2002). In this case study, samplings conducted just after the cave inundation showed a high local extinction rate. In that moment, the community had not been rewarded by the colonization of new species considering the high nestedness values due to species loss. After that, the cave community reached a new balance between extinction and colonization, reflected as the lower species richness in the cave.

Many mechanisms can promote nestedness (Fernández-Juricic, 2002b), such as area size and isolation effects. More isolated and smaller fragments decrease the probability of species occurrence (Lomolino \& Davis, 1997; Fernández-Juricic, 2002b). Considering cave environments, the degree of isolation generally reduces the possibilities of dispersion and consequent migration between caves, while in caves closely located the colonization by others species is usually favored (Jaffé et al., 2016). Additionally, human disturbances can lead to a greatly nested pattern (Fernández-Juricic, 2002b). The nested pattern found in this study was especially high in the first two pairwise comparisons. After the disturbance, the community became a subset of that ocurring in the cave before the the reservour filling. However, the fragment size is expected to change species composition over time (Fernández-Jurici, 2002a), as occurred from the third pairwise comparisons onward, indicated by the high species turnover.

In addition to the beta diversity pattern found after the area loss, some studies have shown that the $z$ value (a constant of the species/area equation) may increase according to the degree of isolation of a particular area (Lomolino, 1984, 2001). It may also vary according to the taxa, functional group, mobility, body-size, local population size and trophic rank of the organisms analyzed (Holt et al., 1999; Woodcock et al., 2006; Cencini et al., 2012). We found a high $z$-value in the species-area curve, what can be related to two principal factors. First, as a consequence of the filling reservoir, the cave was surrounded by water, contributing to a higher remoteness from 
this subterranean habitat. As postulated by Brown (1971), the higher $z$ value found for boreal mammals in relation to the oceanic islands may indicate that such mammals might present exeptionally low rates of immigration between mountains, a situation quite similar to what was observd in this study. Furthermore, we could expect a more drastic effect of area loss, since the cave is located in a very small carbonatic province, the São João Del Rei Group, and no other caves are known for the surroundings, what makes Santo Antônio Cave strongly insulated. The second factor is that cave communities are mainly composed by small troglophilic invertebrates, which can present ecological requirements similar to the environmental conditions observed in caves, preventing them from leaving the hypogean habitat. Furthermore, these species present lower mobility compared with birds and mammals, for which the $z$-value commonly ranges from 0.20 to 0.40 (Rosenzweig, 1995). However, the most commonly used value in fragmented systems (based on empirical studies of birds and mammals) corresponds to $z=0.25$ (Rosenzweig, 1995; Brooks et al., 2002). This commonly used value did not work properly for Brazilian Atlantic Forest fauna. It seems to overestimate predicted extinctions for threatened bird species. Furthermore, models for mammals indicate that they are even more affected by deforestation and therefore present higher $z$-values (Grelle et al., 2005). Accordingly, the two factors mentioned above could contribute together to the higher $z$-value $(0.58)$ for the invertebrate community found in the Santo Antônio Cave.

In conclusion, studies considering the cave community before disturbing events and their responses after such disturbances are critically important to help researchers and decision-makers on drawing conservation actions. Furthermore, such kind of studies, if conducted in a bigger set of caves, will certainly provide empirical evidences to determine extinction rates in a cave before impacts as the observed in this study occur, thus directly contributing for conservation strategies on cave fauna. Surveys conducted previously to the impacts allow a better evaluation if the species loss could in some way be rewarded by the economic growth. This scenario is specially important in Brazil, given the increasing demand for hydropower and mineral resources (Ferreira et al., 2014).

The use of hydropower in Brazil has been growing and $70 \%$ of the country potential remains untapped (Ferreira et al., 2014). The Brazilian energy sector predicts an increase of $55.3 \%$ in the installed capacity of generating electricity until 2024. Furthermore, a strong expansion of mining areas is expected (Brasil Ministério de Minas e Energia, 2015). The Brazilian economic growth is linked to such largescale activities and their evironmental effects over the natural ecosystem are likely to be multiple and severe (Ferreira et al., 2014). The environmental damage caused by extractive activities in Brazil threatens the available subterranean habitats. The Serra da Mesa hydroelectric plant installation in central Brazil covered an area of $1,784 \mathrm{~km}^{2}$ (Fernandez \& Thiengo,
2002), culminating in the flooding of more than 40 caves (CECAV, 2017), without any appropriate study. The present study highlighted that the area loss can cause a drastic change in tropical cave communities, indicating that without urgent conservation strategies, cave species may face massive extinctions due to such enterprises.

\section{Acknowlegments}

We thank our colleagues Érika Linzi S. Taylor, Leopoldo F. O. Bernardi and Marconi S. Silva, for their help in field work. To Xavier Prous for making the maps of spatial representation of species richness distributions. To Paulo S. Pompeu, for his assistance in statistical analyses. Special thanks to David Culver, Juliana Tuller, Carla Ribas and the anonymous reviewer for their valuable suggestions. This paper was partially produced during the course PEC 527 - Publicação Científica of the Graduate Program in Applied Ecology of the Universidade Federal de Lavras. Funil Hydropower Plant Reservoir gave financial support for this study and Thais Giovannini Pellegrini received grants from CAPES and from Vale S.A. RLF is grateful to the Conselho Nacional de Desenvolvimento Científico e Tecnológico (CNPq grant n. 308334/2018-3).

\section{REFERENCES}

Barciová T., Kováč L', Miklisová D., Chlebovská K., Chlebovskỳ O., Ahlers I. \& Bacenková D., 2010 Impact of tourism upon structure and diversity of Collembola assemblages (Hexapoda)-a case study of the Gombasecká Cave, Slovak Karst (Slovakia). Acta Carsologica Slovaca, 48 (2): 271-283.

Baselga A. \& Orme C.D.L., 2012 - betapart: an R package for the study of beta diversity. Methods in Ecology and Evolution, 3 (5): 808-812. https://doi.org/10.1111/j.2041-210X.2012.00224.x

Baselga A., Orme D., Villeger S., De Bortoli J. \& Leprieur F., 2017 - betapart: Partitioning beta diversity into turnover and nestedness components. $\mathrm{R}$ package, version 1.4-1. https://CRAN.R-project.org/package=betapart

Bento D.D.M., Ferreira R.L., Prous X., Souza-Silva M., BelliniB.C. \& Vasconcellos A., 2016-Seasonalvariations in cave invertebrate communities in the semiarid Caatinga, Brazil. Journal of Cave and Karst Studies, 78 (2): 61-71. https://doi.org/10.4311/2015LSC0111 Batucan Jr, L.S. \& Nuñeza O.M., 2013 - Ant species richness in caves of Siargao Island Protected Landscape and Seascape, Philippines. Extreme Life, Biospeology \& Astrobiology, 5 (2): 83-92.

Bernardi L.F.O., Souza-Silva M. \& Ferreira R.L., 2010 - Considerações sobre os efeitos do turismo no ecossistema da Mina do Chico Rei (Ouro Preto, Minas Gerais): implicações para o manejo em sistemas naturais. Turismo e Paisagens Cársticas, 3 (2): 67-77.

Bernarth R.F. \& Kunz T.H., 1981 - Structure and dynamics of arthropod communities in bat guano deposits in buildings. Canadian Journal of Zoology, 59: 260-270. https://doi.org/10.1139/z81-041

Brooks T.M., Mittermeier R.A., Mittermeier C.G., Da Fonseca G.A., Rylands A.B., Konstant W.R., Penny F., Pilgrim J., Oldfield S., Magin G. \& Hilton-Taylor C., 2002 - Habitat loss and extinction in the hotspots of biodiversity. Conservation Biology, 16 (4): 909-923. https://doi.org/10.1046/j.1523-1739.2002.00530.x 
Brown J.H., 1971 - Mammals on mountaintops: nonequilibrium insular biogeography. The American Naturalist, 105: 467-478. https://doi.org/10.1086/282738

CECAV - Centro Nacional de Perquisa e Conservação de Cavernas / Instituto Chico Mendes, 2017 - CANIE - Cadastro Nacional de Informações Espeleológicas. [WWW document].

http://www.icmbio.gov.br/cecav/canie.html [accessed $7^{\text {th }}$ July 2017].

Cencini M., Pigolotti S. \& Muñoz M.A., 2012 - What ecological factors shape species-area curves in neutral models? PLoS One, 7 (6): e38232.

https://doi.org/10.1371/journal.pone.0038232

Chao A., Chazdon R.L., Colwell R.K. \& Shen T.J., 2006 Abundance-based similarity indices and their estimation when there are unseen species in samples. Biometrics, 62: 361-371.

https://doi.org/10.1111/j.1541-0420.2005.00489.x

Clarke K.R. \& Gorley R.N., 2001 - Primer v.5: User manual / Tutorial. Plymouth U.K.

Connor E.F. \& McCoy E.D., 1979 - The statistics and biology of the species-area relationship. The American Naturalist, 113 (6): 791-833.

https://doi.org/10.1086/283438

Culver D.C., 1970 - Analysis of simple cave communities I. Caves as islands. Evolution, 24 (2): 463-474. https://doi.org/10.1111/j.1558-5646.1970.tb01776.x

Culver D.C., Christman M.C., Šereg I., Trontelj P., Sket B., 2004 - The location of terrestrial species-rich caves in a cave-rich area. Subterranean Biology, 2: 27-32.

Culver D.C. \& Pipan T., 2009 - Caves, as islands. In: Gillespie R.G. \& Clauge D.A. (Eds.), Encyclopedia of islands. University of California Press, Berkeley, p. 150-153.

Di Russo C., Carchini G., Rampini M., Lucarelli M. \& Sbordoni V., 1997 - Long term stability of a terrestrial cave community. International Journal of Speleology, 26 (1): 75-88. https://doi.org/10.5038/1827-806X.26.1.7

Eberhard S., 2001 - Cave fauna monitoring and management at Ida Bay, Tasmania. Records of the Western Australia Museum Supplement, 64: 97-104. https://doi.org/10.18195/issn.0313-122x.64.2001. 097-104

Faille A., Bourdeau C. \& Deharveng L., 2015 - Weak impact of tourism activities on biodiversity in a subterranean hotspot of endemism and its implications for the conservation of cave fauna. Insect Conservation and Diversity, 8 (3): 205-215. https://doi.org/10.1111/icad.12097

Faille A., Tänzler R. \& Toussaint E.F., 2015-On the way to speciation: shedding light on the karstic phylogeography of the microendemic cave beetle Aphaenops cerberus in the Pyrenees. Journal of Heredity, 106 (6): 692-699. https://doi.org/10.1093/ihered/esv078

Fernandez M.A. \& Thiengo S.C., $2002-$ Susceptibility of Biomphalaria straminea (Dunker, 1848) from Serra da Mesa Dam, Goiás, Brazil to infection with three strains of Schistosoma mansoni Sambon, 1907. Memórias do Instituto Oswaldo Cruz, 97: 59-60. https://doi.org/10.1590/S0074-02762002000900013

Fernández-Juricic E., 2000a - Bird community composition patterns in urban parks of Madrid: the role of age, size and isolation. Ecological Research, 15 (4): 373-383. https://doi.org/10.1046/j.1440-1703.2000.00358.x

Fernández-Juricic E., 2002b - Can human disturbance promote nestedness? A case study with breeding birds in urban habitat fragments. Oecologia, 131 (2): 269-278. https://doi.org/10.1007/s00442-002-0883-y
Ferreira R.L. \& Horta L.C.S., 2001- Natural and human impacts on invertebrate communities in Brazilian caves. Revista Brasileira de Biologia, 61 (1): 7-17. https://doi.org/10.1590/S0034-71082001000100003

Ferreira J., Aragão L.E.O.C., Barlow J., Barreto P., Berenguer E., Bustamante M., Gardner T.A., Lees A.C., Lima A., Louzada J., Pardini R., Parry L., Peres C.A., Pompeu P.S., Tabarelli M. \& Zuanon J., 2014 - Brazil's environmental leadership at risk. Science, 346: 706707. https://doi.org/10.1126/science.1260194

Ferreira R.L. \& Martins R.P., 1998 - Diversity of spiders associated with bat guano piles in Morrinho Cave (Bahia State, Brazil). Diversity and Distributions, 4: 235-241. https://www.jstor.org/stable/2999829

Ferreira R.L. \& Martins R.P., 1999 - Trophic structure and natural history of bat guano invertebrate communities, with special reference to Brazilian caves. Tropical Zoology, 12 (2): 231-252.

https://doi.org/10.1080/03946975.1999.10539391

Ferreira R.L., Martins R.P. \& Yanega D., 2000 - Ecology of bat guano arthropod communities in a Brazilian dry cave. Ecotropica, 6 (2): 105-116.

Ferreira R.L., 2004 - A medida da complexidade biológica e suas aplicações na Conservação e Manejo de sistemas subterrâneos. 161 f. Thesis (Programa de Ecologia, Conservação e Manejo da Vida Silvestre) Universidade Federal de Minas Gerais.

Ferreira R.L., 2005 - A Vida Subterrânea nos Campos Ferruginosos. O Carste, 3: 106-115.

Ferreira R.L., Prous X. \& Martins R.P., 2007 - Structure of bat guano communities in a dry Brazilian cave. Tropical Zoology, 20: 55-74.

França F., Louzada J., Korasaki V., Griffiths H., Silveira J.M. \& Barlow J., 2016 - Do space-for-time assessments underestimate the impacts of logging on tropical biodiversity? An Amazonian case study using dung beetles. Journal of Applied Ecology, 53 (4): 10981105. https://doi.org/10.1111/1365-2664.12657

Gotelli N.J., 2009 - A primer of ecology (4 ${ }^{\text {th }}$ Ed.). Sinauer Associates, $290 \mathrm{p}$.

Harris J.A., 1970 - Bat-guano cave environment. Science, 90: $160-162$.

https://doi.org/10.1126/science.169.3952.1342-a

Hodkinson I.D. \& Jackson J.K., 2005 - Terrestrial and aquatic invertebrates as bioindicators for environmental monitoring, with particular reference to mountain ecosystems. Environmental Management, 35 (5): 649666. https://doi.org/10.1007/s00267-004-0211-x

Holt R.D., Lawton J.H., Polis G.A. \& Martinez N.D., 1999 - Trophic rank and the species-area relationship. Ecology, 80 (5): 1495-1504.

https://doi.org/10.1890/0012-9658(1999)080 [1495:TRATSA]2.0.CO;2

Iliffe T.M., Hart C.W. \& Manning R.B., 1983-Biogeography and the caves of Bermuda. Nature, 302: 141-142. https://doi.org/10.1038/302141a0

Jaffe R., Prous X., Zampaulo R., Giannini T.C., Imperatriz-Fonseca V.L., Maurity C., Oliveira G., Brandi I.V. \& Siqueira J.O., 2016 - Reconciling mining with the conservation of cave biodiversity: a quantitative baseline to help establish conservation priorities. PLoS One, 11 (12): e0168348.

https://doi.org/10.1371/journal.pone.0168348

Jaffé R., Prous X., Calux A., Gastauer M., Nicacio G., Zampaulo R., Souza-Filho P.W.M., Oliveira G., Brandi I.V. \& Siqueira J.O., 2018 - Conserving relics from ancient underground worlds: assessing the influence of cave and landscape features on obligate iron cave dwellers from the Eastern Amazon. PeerJ, 6: e4531. https://doi.org/10.7717/peerj.4531 
Lomolino M.V., 1984 - Mammalian island biogeography: effects of area, isolation and vagility. Oecologia, 61 (3): 376-382.

https://doi.org/10.1007/BF00379638

Lomolino M.V. \& Davis R., 1997 - Biogeographic scale and biodiversity of mountain forest mammals of western North America. Global Ecology and Biogeography Letters, 6 (1): 57-76.

https://doi.org/10.2307/2997527

Lomolino M.V., 2001 - The species-area relationship: new challenges for an old pattern. Progress in Physical Geography, 25 (1): 1-21.

https://doi.org/10.1191/030913301666288491

MacArthur R.H. \& Wilson E.O., 1963 - An equilibrium theory of insular zoogeogrphy. Evolution, 17: 373-387. https://doi.org/10.1111/j.1558-5646.1963.tb03295.x

MacArthur R.H. \& Wilson E.O., 1967 - The theory of Island Biogeography. Princeton University Press, Princeton, $224 \mathrm{p}$.

May R.M., Lawton J.H. \& Stork N.E., 1995 - Assessing extinction rates. In: Lawton J.H. \& May R.M. (Eds.), Extinction rates. Oxford University Press, Oxford, p. 1-24.

Moldovan O.T., Racovitza G. \& Rajka G., 2003 - The impact of tourism in Romanian show caves: the example of the beetle populations in the Ursilor Cave of Chiscau (Transylvania, Romania). Subterranean Biology, 1: 73-78.

Mulec J., 2014 - Human impact on underground cultural and natural heritage sites, biological parameters of monitoring and remediation actions for insensitive surfaces: Case of Slovenian show caves. Journal for Nature Conservation, 22 (2): 132-141. https://doi.org/10.1016/j.jnc.2013.10.001

Pellegrini T.G. \& Ferreira R.L., 2012 - Management in a neotropical show cave: planning for invertebrates conservation. International Journal of Speleology, 41: 359-366. https://doi.org/10.5038/1827-806X.41.2.19

Pinto-da-Rocha R., 1995 - Sinopse da fauna cavernícola do Brasil (1907-1994). Papéis Avulsos de Zoologia, 39 (6): 61-172.

Poulson T.L. \& White W.B., 1969 - The cave environment. Science, 165: 971-981.

https://doi.org/10.1126/science.165.3897.971

Poulson T.L., 1972 - Bat guano ecosystems. Bulletin of the National Speleological Society, 34: 55-59.

Prous X., Ferreira R.L. \& Jacobi C.M., 2015 - The entrance as a complex ecotone in a Neotropical cave. International Journal of Speleology, 44 (2): 177-189. https://doi.org/10.5038/1827-806X.44.2.7

$\mathrm{R}$ Core Team, 2016 - R: A language and environment for statistical computing. R Foundation for Statistical Computing, Vienna, Austria. https://www.R-project.org/

Rabelo L.M., Souza-Silva M. \& Ferreira R.L., 2018 Priority caves for biodiversity conservation in a key karst area of Brazil: comparing the applicability of cave conservation indices. Biodiversity and conservation, 27 (9): 2097-2129.

https://doi.org/10.1007/s10531-018-1554-6

Romero A., 2009 - Cave biology. Cambridge University Press, New York, 306 p.

https://doi.org/10.1017/CBO9780511596841

Rosenzweig M.L., 1995 - Species diversity in space and time. Cambridge University Press, Cambridge, 436 p. https://doi.org/10.1017/CBO9780511623387

Rybicki J. \& Hanski I., 2013 - Species-area relationships and extinctions caused by habitat loss and fragmentation. Ecology Letters, 16 (1): 27-38. https://doi.org/10.1111/ele.12065

Schneider K., Christman M.C. \& Fagan W.F., 2011 - The influence of resource subsidies on cave invertebrates: results from an ecosystem-level manipulation experiment. Ecology, 92 (3): 765-776.

https://doi.org/10.1890/10-0157.1

Simberloff D., 1992 - Conservation of pristine habitats and unintended effects of biological control. In: Kauffman W.C. \& Nechols J.E. (Eds.), Selection criteria and ecological consequences of importing natural enemies. Entomological Society of America, Lanham, Maryland, p. 103-117.

Simões M.H., Souza-Silva M. \& Ferreira R.L., 2015 - Cave physical attributes influencing the structure of terrestrial invertebrate communities in Neotropics. Subterranean Biology, 16: 103-121.

https://doi.org/10.3897/subtbiol.16.5470

Snowman C.V., Zigler K.S. \& Hedin M., 2010 - Caves as islands: mitochondrial phylogeography of the cave-obligate spider species Nesticus barri (Araneae: Nesticidae). Journal of Arachnology, 38 (1): 49-56. https://doi.org/10.1636/A09-057.1

Souza-Silva M., Martins R.P. \& Ferreira R.L., 2011 - Trophic dynamics in a neotropical limestone cave. Subterranean Biology, 9: 127-138. https://doi.org/10.3897/subtbiol.9.2515

TerraSeer Inc. Software for Geographic Boundary Analysis. http://www.terraseer.com [accessed: July, 2005].

Tjørve E. \& Tjørve K.M., 2008 - The species-area relationship, self-similarity, and the true meaning of the z-value. Ecology, 89 (12): 3528-3533.

https://doi.org/10.1890/07-1685.1

Wickham H., 2009 - ggplot2: elegant graphics for data analysis. Springer, London, $210 \mathrm{p}$. https://doi.org/10.1007/978-0-387-98141-3

Wilson E.O., 2010 - Island biogeography in the 1960s, theory and experiment. In: Losos J.B. \& Ricklefs R.E. (Eds.), The theory of Island Biogeography revisited. Princeton University Press, Princeton, p. 1-12. https://doi.org/10.1515/9781400831920.1 
